Manuscript received 01.11.2019

Accepted: 06.07.2020

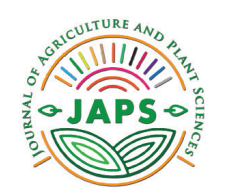

In print: ISSN 2545-4447

On line: ISSN 2545-4455

doi: https://doi.org/10.46763/JAPS2010023g

Professional paper

\title{
SPECIFICS OF SYMBIOTIC NITROGEN FIXATION OF CHICKPEA (Cicer arietinum L.)
}

\author{
Monika Gligorova ${ }^{1}$ \\ 'Goce Delcev University - Stip, Faculty of Agriculture, Krste Misirkov, 10-A, P.O. box 201, 2000 Stip, \\ Republic of Macedonia \\ *Corresponding author: monika.gligorova@gmail.com
}

\begin{abstract}
Nitrogen is a limiting nutrient for plant growth and development. The ability to use nitrogen from the air by leguminous plants is their well-known feature. Nitrogen is present in the gaseous atmosphere $\left(\mathrm{N}_{2}\right)$ at about $78.1 \%$ by volume or $75.51 \%$ by weight, ie a total of $3.8 \times 1015 \mathrm{t}$ or $86.5 \mathrm{t} / \mathrm{ha}$. However, atmospheric nitrogen, in reality, does not receive the plants directly from the air, but rather through previous adoption by Rhizobium bacteria living in the form of small tumors, called nodules on the roots of plants. These bacteria can fix nitrogen gas from the air in the soil and turn it into ammonia $\left(\mathrm{NH}_{3}\right)$, which is converted into ammonium $\left(\mathrm{NH}_{4}\right)$, which the plant can use.

Chickpea (Cicer arietinum L.) is a leguminous plant that has great agrotechnical significance. Characteristic of chickpeas as well as other legumes is that they enter symbiosis with nitrogen-fixing bacteria and can thus use fixed atmospheric nitrogen.

This paper presents and elaborates on the results of agrochemical analyzes of soil in the experiment with chickpea, ie differences in nitrogen content at the beginning and at the end of vegetation. The results show that the nitrogen content in the soil increased by $0.30 \mathrm{mg} / \mathrm{g}$ after the end of the vegetation in 2018 and 0.31 $\mathrm{mg} / \mathrm{g}$ in 2019.
\end{abstract}

Key words: root, inoculation, nodules, soil

\section{INTRODUCION}

Chickpea (Cicer arietinum L.) - predominantly agricultural and garden culture, which is mostly cultivated in Macedonia and Dalmatian Zagora, is considered one of the earliest cultivated plants and its remains are found in the Middle East, up to 7,500 years old (Hillman, 1975). Chickpea is a leguminous plant that is used in people's diet. Seed of chickpea is similar to soybean seeds or dried beans, is used as a pot or as an addition to other vegetables when preparing food. Characteristic of the noodle as well as other legumes is that it comes into symbiosis with nitrogen-fixing bacteria and thus can receive atmospheric nitrogen. This interaction occurs when the roots of the plants secrete flavonoids that are recognized by certain bacteria that infiltrate the root and form nodules where the bacteria are equilibrated and the plants receive nutrients from the plants. These bacteria can fix nitrogen gas from the air into the soil and turn it into an ammonia $\left(\mathrm{NH}_{3}\right)$ that turns into ammonium $\left(\mathrm{NH}_{4}\right)$ that can be used by the plant. The process of fixing nitrogen $\left(\mathrm{N}_{2}-\right.$ fixation) between plants and bacteria is called a symbiotic (mutually beneficial) connection. Every organism gets something from the other and gives back something in return. Rhizobium bacteria supply plants with nitrogen in the form of ammonium, and plants provide bacteria with carbohydrates as a source of energy. The rate of $\mathrm{N}_{2}$-fixation is directly related to the plant growth rate of plants. Everything that reduces the growth of plants, such as drought, low temperature, limited plant nutrients, or diseases will also reduce the $\mathrm{N}_{2}$ fixation. Maintaining a sufficient leaf surface is also critical to maintaining a high growth rate to support the fixation of $\mathrm{N}_{2}$. 


\section{MECHANISM OF INFECTION}

Rhizobia are free, soil saprophytes, living in symbiosis with plants from Fabaceae family. Rhizobia, once inoculated in the soil, may remain low in the absence of an appropriate host (Howieson, 1995). Plant begins a symbiosis with secretion of flavonoids, which are detected by bacteria. Flavonoids vary among different plant species and are recognized only by specific, but specific, bacterial species (Hassan \& Mathesius, 2012). Flavonoids with diffusion penetrate the membrane of bacteria and induce the synthesis of NodD protein to activate the transcription of other genes involved in nodulation, including the production of Nod factor. Node factor is the primary molecule of the signal produced by the bacteria and is detected by the plant to induce nodular organogenesis. Structured Nod factor are lipohytoligosaccharides (LCOs) with a chitin oligomer pillar (Oldroyd \& Downey, 2008). The nod $A B C$ genes encode the proteins needed to make the basic structure of the nod factor and are conserved in all types of rhizobia, with the exception of two species of Aeschynomene (Perret et al., 2000, Giraud et al., 2007). The kernel of the nod factor is then modified with species-specific proteins, resulting in various substitutions including glycosylation and sulphation (Long, 1996). These substitutions are specific to each host and offer another level of specificity of symbiosis (Dénarié et al., 1996; Long, 1996). Many surface polysaccharides are also involved in the specificity of the symbiosis, including lipopolysaccharides (LPSs), extracellular polysaccharides (EPSs), and capsular saccharides. The specific structure of lipohytoligosaccharides is known to be important for recognition by the Nodin host factor (NFRs) receptors that contain lysine (Endre et al., 2002).

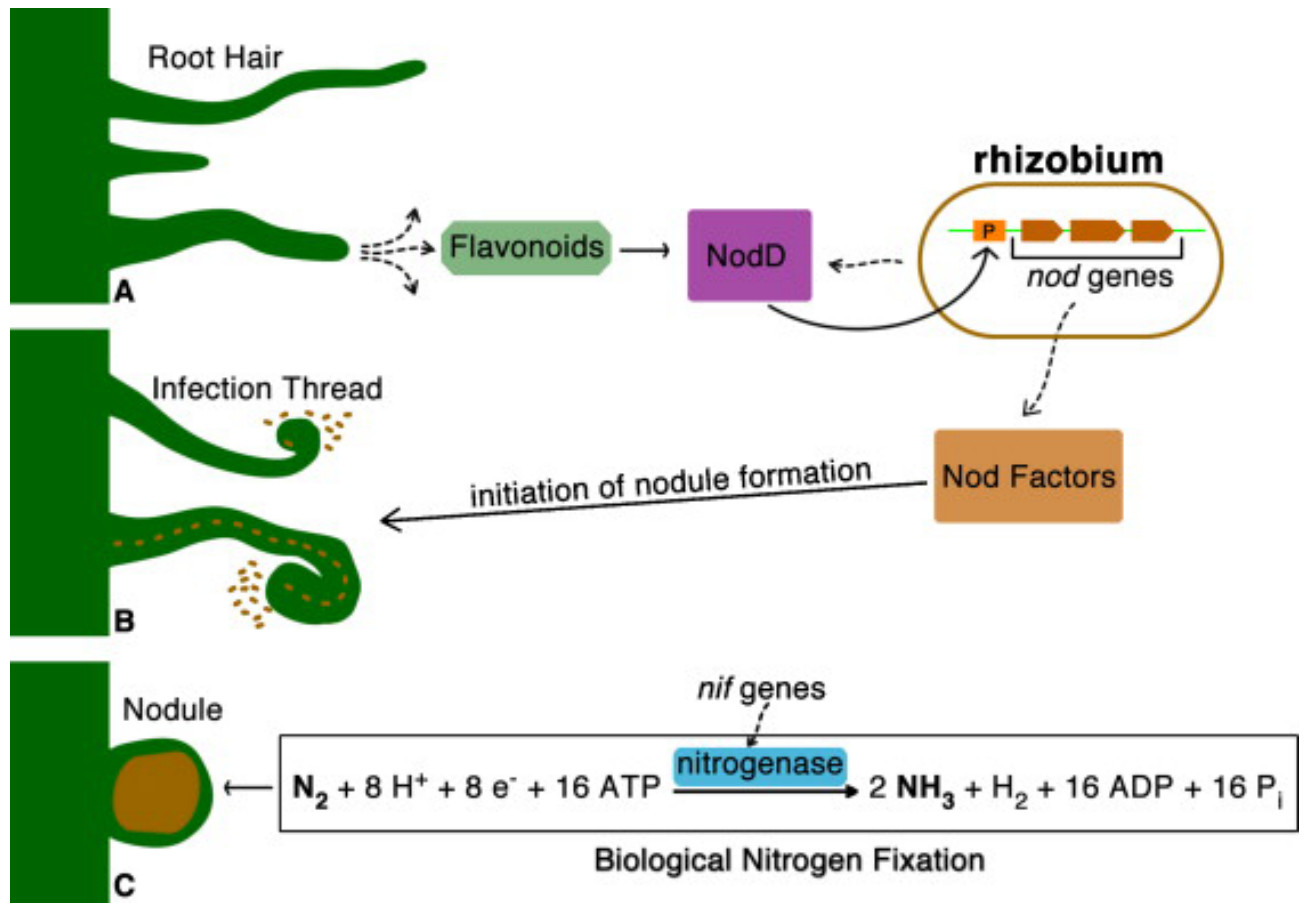

Figure 1. Mechanism of infection

(Resource: https://www.sciencedirect.com/science/article/pii/S0944501313001651)

Bending of root fibers and damage are the two mechanisms of infection that bacteria use. The entrance to the crack includes a rhizobium that enters through cracks on the lateral roots or stems (Goormachtig et al., 2004). Bending the root fibers implies recognition of the nod factor, resulting in bending of the root fibers. This is thought to involve a change in the polarity of plant cells, resulting in a new direction of growth at the root of the root (Gage, 2004). Next, the growth of the root peak changes from radial to polar elongation at the top. The continued growth of infection depends on the specificity of the nod factor, as well as the 
extracellular polysaccharides (Jones et al., 2007). Both the epidermis and the cortex recognize the nod factor, the epidermis regulates bacterial infection, and the root cortex is responsible for the formation of nodules. Cortical cells develop into a nodulus duodenum. When the end of the infection reaches the primordium of the nodules, the rhizobium will enter the internal cells and become encapsulated within the peribacteroid membrane (Oldroys \& Downey, 2008).

\section{MATERIAL AND METHODS}

For this work on the experimental field of the Goce Delcev University in the village of Pishirovo, Sveti Nikole were placed 8 varieties of chickpeas, of which 7 were Turkish (Gulumser, Cevdetbey, Azizyye, Yasa, Inci, Galatay and Azkan) and 1 domestic Macedonian variety with small grains. The trial was established on 04.04.2018 and the harvest took place on August 6, 2018, the length of the vegetation was 120 days. The soil was halomorphic, alkaline and poor with humus.

The varieties were placed in 3 repetitions per random block system and each variety was placed on an area of $10 \mathrm{~m}^{2}$. The interval distance was $50 \mathrm{~cm}$ and in the order of $5 \mathrm{~cm}$. Seeds were not previously inoculated. The purpose of this study was to make a comparison of the amount of nitrogen that nitrogen fixing bacteria fixated in this case Rhizobium ciceri, turned unavailable nitrogen from the atmosphere to the available ammonia $\mathrm{NH}_{3}$.

Before starting the experiment, we measured the moisture and hectoliter mass of the seeds. Table 1 shows the percentage of moisture and hectoliter mass of the seeds.

Table 1. Moisture percentage and hexahedral mass of the seeds



${ }^{*}$ The mass of grain that fits into a specified volume and it is reported in kilograms per hectolitre (g.hL-1)

We also examined seed germination percentage under controlled conditions.

Table 2 shows the germination percentage of the seeds.

Table 2. Seed germination percentage

\begin{tabular}{|c|c|}
\hline Variety & Germination percentage* $(\%)^{*}$ \\
\hline 1. Gulumser & 96 \\
\hline 2. Cevdetbey & 99 \\
\hline 3. Aziziye & 93 \\
\hline 4. Yasa & 99 \\
\hline 5. Inci & 100 \\
\hline 6. Galatay & 94 \\
\hline 7. Azkan & 95 \\
\hline 8. Domestic & 99 \\
\hline
\end{tabular}

GP = seeds germinated/total seeds $\mathrm{x} 100$

\section{RESULTS AND DISCUSSION}

In order to compare the amount of nitrogen in the soil, agrochemical analysis were made at the beginning and at the end of the vegetation.
The Tables 3 and 4 show the results from the agrochemical analysis. 
Table 3. Result from the agrochemical analysis at the beginning of vegetation (2018).

\begin{tabular}{|c|c|c|c|c|c|}
\hline \multicolumn{2}{|c|}{ Parameter } & Value & Measuring unit & Soil classification & Method \\
\hline \multirow{2}{*}{$\mathrm{pH}$} & $\mathrm{KCl}$ & 7.53 & I & very low alkaline & \multirow{2}{*}{ ISO- 10390:2005 (E)* } \\
\hline & $\mathrm{H}_{2} \mathrm{O}$ & 8.34 & / & alkaline & \\
\hline \multicolumn{2}{|c|}{$\mathrm{EC}(1: 2)$} & 0.32 & $\mathrm{mS} / \mathrm{cm}$ & optimal & $\begin{array}{l}\text { Electrical Conductivity: } \\
\text { A County Extension Soil } \\
\text { Laboratory Manual, E. A. } \\
\text { Hanlon, Jr. }\end{array}$ \\
\hline \multicolumn{2}{|c|}{ total $\mathrm{N}$} & 1.57 & $\mathrm{mg} / \mathrm{g}$ & good nitrogen supply & ISO 11261:1995 (E) \\
\hline \multicolumn{2}{|c|}{ available $\mathrm{P}_{2} \mathrm{O}_{5}$} & 71.52 & $\mathrm{mg} / 100 \mathrm{~g}$ & $\begin{array}{l}\text { good phosphorus } \\
\text { supply }\end{array}$ & $\begin{array}{l}\text { Modified method for the } \\
\text { determination of readily } \\
\text { available phosphorus and } \\
\text { potassium soil samples with } \\
\text { AL method according to } \\
\text { Egnér, Riehm, Domingo }\end{array}$ \\
\hline \multicolumn{2}{|c|}{ available $\mathrm{K}_{2} \mathrm{O}$} & 87.53 & $\mathrm{mg} / 100 \mathrm{~g}$ & good potassium supply & $\begin{array}{l}\text { Modified method for the } \\
\text { determination of readily } \\
\text { available phosphorus and } \\
\text { potassium soil samples with } \\
\text { AL method according to } \\
\text { Egnér, Riehm, Domingo } \\
\end{array}$ \\
\hline \multicolumn{2}{|c|}{ humus } & 2.42 & $\%$ & $\begin{array}{l}\text { poorly supplied with } \\
\text { humus }\end{array}$ & $\begin{array}{l}\text { Chemical methods of soil } \\
\text { testing, Stojanović } 1966\end{array}$ \\
\hline
\end{tabular}

* accredited methods

Table 4. Results from the agrochemical analysis at the end of vegetation (2018).

\begin{tabular}{|c|c|c|c|c|c|}
\hline \multicolumn{2}{|c|}{ Parameter } & Value & Measuring unit & Soil classification & Method \\
\hline \multirow{2}{*}{$\mathrm{pH}$} & $\mathrm{KCl}$ & 7.62 & I & & \multirow{2}{*}{ ISO- 10390:2005 (E) } \\
\hline & $\mathrm{H}_{2} \mathrm{O}$ & 8.31 & I & alkaline & \\
\hline \multicolumn{2}{|c|}{$\mathrm{EC}(1: 2)$} & 0.43 & $\mathrm{mS} / \mathrm{cm}$ & optimal & $\begin{array}{l}\text { Electrical Conductivity: } \\
\text { A County Extension Soil } \\
\text { Laboratory Manual, E. A. } \\
\text { Hanlon, Jr. }\end{array}$ \\
\hline \multicolumn{2}{|c|}{ total $\mathrm{N}$} & 1.80 & $\mathrm{mg} / \mathrm{g}$ & good nitrogen supply & ISO 11261:1995 (E) \\
\hline \multicolumn{2}{|c|}{ available $\mathrm{P}_{2} \mathrm{O}_{5}$} & 65.60 & $\mathrm{mg} / 100 \mathrm{~g}$ & $\begin{array}{l}\text { good phosphorus } \\
\text { supply }\end{array}$ & $\begin{array}{l}\text { Modified method for the } \\
\text { determination of readily } \\
\text { available phosphorus and } \\
\text { potassium soil samples with } \\
\text { AL method according to } \\
\text { Egnér, Riehm, Domingo } \\
\end{array}$ \\
\hline \multicolumn{2}{|c|}{ available $\mathrm{K}_{2} \mathrm{O}$} & 83.35 & $\mathrm{mg} / 100 \mathrm{~g}$ & good potassium supply & $\begin{array}{l}\text { Modified method for the } \\
\text { determination of readily } \\
\text { available phosphorus and } \\
\text { potassium soil samples with } \\
\text { AL method according to } \\
\text { Egnér, Riehm, Domingo }\end{array}$ \\
\hline \multicolumn{2}{|c|}{ humus } & 2.80 & $\%$ & $\begin{array}{l}\text { poorly supplied with } \\
\text { humus }\end{array}$ & $\begin{array}{l}\text { Chemical methods of soil } \\
\text { testing, Stojanović } 1966\end{array}$ \\
\hline
\end{tabular}


Table 5. Result from the agrochemical analysis at the beginning of vegetation (2019)

\begin{tabular}{|c|c|c|c|c|c|}
\hline \multicolumn{2}{|c|}{ Parameter } & Value & Measuring unit & Soil classification & Method \\
\hline \multirow{2}{*}{$\mathrm{pH}$} & $\mathrm{KCl}$ & 7.54 & I & very low alkaline & \multirow{2}{*}{ ISO- 10390:2005 (E) } \\
\hline & $\mathrm{H}_{2} \mathrm{O}$ & 8.23 & I & alkaline & \\
\hline \multicolumn{2}{|c|}{$\mathrm{EC}(1: 2)$} & 0.71 & $\mathrm{mS} / \mathrm{cm}$ & optimal & $\begin{array}{l}\text { Electrical Conductivity: } \\
\text { A County Extension Soil } \\
\text { Laboratory Manual, E. A. } \\
\text { Hanlon, Jr. }\end{array}$ \\
\hline \multicolumn{2}{|c|}{ total $\mathrm{N}$} & 1.09 & $\mathrm{mg} / \mathrm{g}$ & good nitrogen supply & ISO 11261:1995 (E) \\
\hline \multicolumn{2}{|c|}{ available $\mathrm{P}_{2} \mathrm{O}_{5}$} & 77.36 & $\mathrm{mg} / 100 \mathrm{~g}$ & $\begin{array}{l}\text { good phosphorus } \\
\text { supply }\end{array}$ & $\begin{array}{l}\text { Modified method for the } \\
\text { determination of readily } \\
\text { available phosphorus and } \\
\text { potassium soil samples with } \\
\text { AL method according to } \\
\text { Egnér, Riehm, Domingo }\end{array}$ \\
\hline \multicolumn{2}{|c|}{ available $\mathrm{K}_{2} \mathrm{O}$} & 125.67 & $\mathrm{mg} / 100 \mathrm{~g}$ & good potassium supply & $\begin{array}{l}\text { Modified method for the } \\
\text { determination of readily } \\
\text { available phosphorus and } \\
\text { potassium soil samples with } \\
\text { AL method according to } \\
\text { Egnér, Riehm, Domingo }\end{array}$ \\
\hline \multicolumn{2}{|c|}{ humus } & 2.51 & $\%$ & $\begin{array}{l}\text { poorly supplied with } \\
\text { humus }\end{array}$ & $\begin{array}{l}\text { Chemical methods of soil } \\
\text { testing, Stojanović } 1966\end{array}$ \\
\hline
\end{tabular}

Table 6. Results from the agrochemical analysis at the end of vegetation (2019)

\begin{tabular}{|c|c|c|c|c|c|}
\hline \multicolumn{2}{|c|}{ Parameter } & Value & Measuring unit & Soil classification & Method \\
\hline \multirow{2}{*}{$\mathrm{pH}$} & $\mathrm{KCl}$ & 7.71 & / & very low alkaline & \multirow{2}{*}{ ISO- 10390:2005 (E) } \\
\hline & $\mathrm{H}_{2} \mathrm{O}$ & 8.50 & I & alkaline & \\
\hline \multicolumn{2}{|c|}{$\mathrm{EC}(1: 2)$} & 0.65 & $\mathrm{mS} / \mathrm{cm}$ & optimal & $\begin{array}{l}\text { Electrical Conductivity: } \\
\text { A County Extension Soil } \\
\text { Laboratory Manual, E. A. } \\
\text { Hanlon, Jr. }\end{array}$ \\
\hline \multicolumn{2}{|c|}{ total $\mathrm{N}$} & 1.40 & $\mathrm{mg} / \mathrm{g}$ & good nitrogen supply & ISO 11261:1995 (E) \\
\hline \multicolumn{2}{|c|}{ available $\mathrm{P}_{2} \mathrm{O}_{5}$} & 58.36 & $\mathrm{mg} / 100 \mathrm{~g}$ & $\begin{array}{l}\text { good phosphorus } \\
\text { supply }\end{array}$ & $\begin{array}{l}\text { Modified method for the } \\
\text { determination of readily } \\
\text { available phosphorus and } \\
\text { potassium soil samples with } \\
\text { AL method according to } \\
\text { Egnér, Riehm, Domingo }\end{array}$ \\
\hline \multicolumn{2}{|c|}{ available $\mathrm{K}_{2} \mathrm{O}$} & 174.04 & $\mathrm{mg} / 100 \mathrm{~g}$ & good potassium supply & $\begin{array}{l}\text { Modified method for the } \\
\text { determination of readily } \\
\text { available phosphorus and } \\
\text { potassium soil samples with } \\
\text { AL method according to } \\
\text { Egnér, Riehm, Domingo }\end{array}$ \\
\hline \multicolumn{2}{|c|}{ humus } & 2.73 & $\%$ & $\begin{array}{l}\text { poorly supplied with } \\
\text { humus }\end{array}$ & $\begin{array}{l}\text { Chemical methods of soil } \\
\text { testing , Stojanović } 1966\end{array}$ \\
\hline
\end{tabular}


From the results (Table 3, 4, 5 and 6), we can see the difference in the available nitrogen from $1.57 \mathrm{mg} / \mathrm{g}$ to $1.80 \mathrm{mg} / \mathrm{g}$ in year 2018 and from $1.09 \mathrm{mg} / \mathrm{g}$ to $1.40 \mathrm{mg} / \mathrm{g}$ and to conclude that the chickpea fixed $0.23 \mathrm{mg} / \mathrm{g}$ of nitrogen (2018) and $0.31 \mathrm{mg} / \mathrm{g}$ (2019). Regarding the varieties we had a difference regarding the formation of nodules, in certain varieties were more effectively involved in symbiosis with bacteria. Most nodules were formed in the Cevdetbey variety. Apart from more nodules, plants of this variety have formed the largest seeds. Apart from differences in nitrogen, we also have differences in the humus content of the soil. Before the vegetation the content of humus was $2.42 \%$ and at the end of the vegetation $2.80 \%$ in 2018 and in 2019 the content of humus at the beginning of the vegetation was $2.50 \%$ and at the end was $2.73 \%$. This is due to the increased activity of microorganisms that break down organic matter and make it available to plants, thereby increasing fertility of the soil.



Figure 2. Nodule on the root of chickpea.

(Resource: http://eagri.org/eagri50/AMBE101/lec18.html)

\section{CONCLUDING REMARKS}

Symbiotic nitrogenation (SNF) is an important biological feature that allows leguminous plants to grow efficiently in conditions of nitrogen restriction and also have significant agronomic and environmental benefits. Due to their unique ability to form a symbiotic relationship with a group of nitrogen fixating bacteria called "Rhizobia", the beans represent an important and diverse plant group.

The bacteria fixes the atmospheric $\mathrm{N}_{2}$ to ammonia for direct plant use.

In our experiments we proved that the chickpea enriches the soil with nitrogen for 0.30 $\mathrm{mg} / \mathrm{g}$ in 2018 and $0.31 \mathrm{mg} / \mathrm{g}$ in 2019.
Also we can conclude that apart from the increased nitrogen content, we have an increased quantity of humus-specific complex of nitrogen compounds that occur due to the mineralization of plant residues under the influence of enzymes released from microorganisms living in the soil.

That significantly affects the bulk density of soil and contributes to its retention of moisture and nutrients.

Therefore, the cultivation of leguminous plants is recommended, in this case, the chickpea in crop rotation. 


\title{
REFERENCES
}

Dénarié, J., Debellé, F., Promé, J.C. (1996). Rhizobium lipo-chitooligosaccharide nodulation factors: signaling molecules mediating recognition and morphogenesis. Annu. Rev. Biochem., 65 503-535.

Endre, G., Kereszt, A., Kevei, Z., Mihacea, S., Kalo, P., Kiss, G. B. (2002). A receptor kinase gene regulating symbiotic nodule development. Nature, 417, 962-966.

Gage, D.J. (2004). Infection and invasion of roots by symbiotic, nitrogen-fixing rhizobia during nodulation of temperate legumes. Microbiol. Mol. Biol. Rev., 68, 280-300.

Goormachtig, S., Capoen, W., Holsters, M. (2004). Rhizobium infection: lessons from the versatile nodulation behaviour of water-tolerant legumes. Trends Plant Sci., 9, 518-522.

Гугувчевски, М. (1972). Зрнести и клубенести култури, Универзитет „Кирил и Методиј", Земјоделски факултет, Скопје.

Hassan, S., Mathesius, U. (2012). The role of flavonoids in root-rhizosphere signalling: opportunities and challenges for improving plant-microbe interaction. J. Exp. Bot., 63, 3429-3444.

Hillman, G.C. (1975). The plant remains from

Tell Abu Hureya in Syria: a preliminary report. In the excavation of Tell Abu Hureya in Syria: a preliminary report, A.M.T.Moore. Proceedings of the Prehistory Society, 41, 70-73.

Howieson, J.G. (1995). Biserrula pelecinusL. - a legume pasture species with potential for acid, duplex soils which is nodulated by unique root-nodule bacteria. Aust J Agric Res, 46, 9971009.

Jones, J.D.G. \& Dangl, J.L. (2006). The plant immune system. Nature, 444 323-329.

Long, S.R. (1996). Rhizobium symbiosis: nod factors in perspective. Plant Cell, 8 18851898.

Oldroy, G. (2008). Coordinating nodule morphogenesis with rhizobial infection in legumes. Annu Rev Plant Biol., 519-546.

Perret, X., Staehelin, C., Broughton, W.J. (2000). Molecular basis of symbiotic promiscuity. Microbiol. Mol. Biol. Rev., 64, 180-201.

Василевски, Г. (2004). Зрнести и клубенести култури, Скопје.

https://www.sciencedirect.com/science/ article/pii/S0944501313001651

http://eagri.org/eagri50/AMBE101/lec18. $\underline{\mathrm{html}}$

\section{СПЕЦИФИЧНОСТИ НА СИМБИОТСКА АЗОТОФИКСАЦИЈА КАЈ НАУТ (Cicer arietinum L.)}

\author{
Моника Глигорова ${ }^{{ }^{*}}$ \\ 'Студент на втор ииклус студии, Земјоделски факултет, Универзитет „Гоче Делчев" - Штип, \\ Република Северна Македонија \\ *Контакт автор: monika.gligorova@gmail.com
}

\section{Резиме}

Азотот е ограничувачки хранлив елемент за растот и развитокот на растенијата. Способноста да се користи азотот од воздухот од страна на легуминозните растенија е нивна добро позната карактеристика. Азотот се наоѓa во атмосферата во гасовита форма $\left(\mathrm{N}_{2}\right)$ околу 78,1\% волуменски или 75,51\% тежински, односно вкупно 3,8x1015 t или 86,5 t/ha. Сепак, атмосферскиот азот, во реалноста, растенијата не го примаат директно од воздухот, туку преку претходно усвојување од страна на Rhizobium бактериите кои живеат во вид на мали тумори, наречени нодули на корените на растенијата. Овие бактерии можат да го фиксираат азотниот гас од воздухот во почвата и да го претворат во амонијак $\left(\mathrm{NH}_{3}\right)$, кој се претвора во амониумова форма $\left(\mathrm{NH}_{4}\right)$, што може да ја користи растението.

Наутот (Cicer arietinum L.) е легуминозно растение, кое има големо агротехничко значење. Карактеристично за наутот како и за другите легуминози е тоа што стапува во симбиоза со азотофиксирачки бактерии и на тој начин може да го користи фиксираниот атмосферски азот.

Во овој труд се прикажани и образложени резултатите од агрохемиските анализи на почвата во опитот со наут, односно разликите во количината на азот на почетокот и на крајот од вегетацијата. Од резултатите може да се види дека количините на азот во почвата се зголемиле за $0.30 \mathrm{mg} / \mathrm{g}$ по завршување на вегетацијата на наутот во 2018 година и $0.31 \mathrm{mg} / \mathrm{g}$ во 2019 година.

Клучни зборови: симбиоза, инокулација, нодули, почва 